\title{
Cell-gel interactions of in-gel propagating bacteria
}

\author{
Philip Serwer $^{1 *}$ (D), Barbara Hunter ${ }^{2}$ and Elena T. Wright ${ }^{1}$
}

\begin{abstract}
Objective: Our immediate objective is to test the data-suggested possibility that in-agarose gel bacterial propagation causes gel fiber dislocation and alteration of cell distribution. We also test the further effect of lowering water activity. We perform these tests with both Gram-negative and Gram-positive bacteria. Data are obtained via electron microscopy of thin sections, which provides the first images of both bacteria and gel fibers in gel-supported bacterial lawns. The long-term objective is analysis of the effects of in-gel propagation on the DNA packaging of phages.

Results: We find that agarose gel-supported cells in lawns of Escherichia coli and Lysinibacillus (1) are primarily in clusters that increase in size with time and are surrounded by gel fibers, and (2) sometimes undergo gel-induced, post-duplication rotation and translation. Bacterial growth-induced dislocation of gel fibers is observed. One reason for clustering is that clustering promotes growth by increasing the growth-derived force applied to the gel fibers. Reactive force exerted by gel on cells explains cell movement. Finally, addition to growth medium of $0.94 \mathrm{M}$ sucrose causes cluster-associated E. coli cells to become more densely packed and polymorphic. Shape is determined, in part, by neighboring cells, a novel observation to our knowledge.
\end{abstract}

Keywords: Bacterial clustering, Bacterial plasticity, Electron microscopy, In-gel bacterial propagation, Thin sections

\section{Introduction}

Bacterial cells propagate in a polymer gel when in either (1) a lawn for plaque assay of phages (recent references $[1,2]$ ) or (2) a biofilm [3-5]. But, the supporting gel's influence on the cells is not known. Agar gels are typically used $[1,2]$, although recent studies have shown that polyacrylamide gels can also be used [6]. Analysis is optimally done with procedure, such as used here, that reveals both cells and gel fibers.

In theory, bacterial propagation in an agarose gel is constrained by agarose fibers, which are rigid to thermal motion [7]. Indeed, if these fibers are unbroken and rigid to bacterial motion, in-gel bacteria could not duplicate when the diameter of the gel's effective pore $\left(2 \times P_{\mathrm{E}}\right)$ is smaller than bacterial cell dimensions. In liquid media, Escherichia coli has diameter of $\sim 1000 \mathrm{~nm}$ and length of

\footnotetext{
*Correspondence: serwer@uthscsa.edu

${ }^{1}$ Department of Biochemistry and Structural Biology, The University

of Texas Health Science Center, 7703 Floyd Curl Drive, San Antonio, TX

78229-3900, USA

Full list of author information is available at the end of the article
}

2000-5000 nm [8]. Studies of gel electrophoretic sieving yield a smaller $2 \times P_{\mathrm{E}}$ of $462 \mathrm{~nm}$ for $0.6 \%$ underivatized agarose; $P_{\mathrm{E}}$ decreases as agarose concentration increases [9]. But, here we propagate E. coli in $0.6 \%$ agarose gels. Also, elongation of single $E$. coli cells is observed by light microscopy in (1) $1 \%$ hydroxyethyl agarose gels [10] $\left(P_{\mathrm{E}}=113 \mathrm{~nm}\right.$ [9]) and (2) 8\% underivatized agarose gels [11] $\left(2 \times P_{\mathrm{E}}<60 \mathrm{~nm}\right.$ [9]). Tryptone, as used in media here, combines with bacteria to increase gel stiffness [10].

In-gel propagability of $E$. coli suggests, therefore, that cell growth-induced dislocation of gel fibers occurs. However, no observation has, to our knowledge, been made of gel fibers after in-gel bacterial duplication. Our interest originated during analysis of in-plaque phage DNA packaging. Here, we use electron microscopy (EM) of thin sections to achieve this observation for bacterial propagation in agarose gels; gel swelling during sectioning prevents this analysis of polyacrylamide gels [12].

(c) The Author(s) 2018. This article is distributed under the terms of the Creative Commons Attribution 4.0 International License (http://creativecommons.org/licenses/by/4.0/), which permits unrestricted use, distribution, and reproduction in any medium, provided you give appropriate credit to the original author(s) and the source, provide a link to the Creative Commons license, and indicate if changes were made. The Creative Commons Public Domain Dedication waiver (http://creativecommons.org/ publicdomain/zero/1.0/) applies to the data made available in this article, unless otherwise stated. 


\section{Main text \\ Methods \\ Bacterial strains}

Escherichia coli BB/1 (host for phages T3 and T7 [13]) and a Lysinibacillus are used here as Gram-negative and Gram-positive bacteria, respectively. The Lysinibacillus is host for phage $\mathrm{G}$ (Lysinibacillus PGH). It was typed via commercial sequencing and informatic analysis (J.A. Thomas, W. Jiang and P. Serwer, unpublished). It had previously been mis-identified as Bacillus megaterium PGH [14], which, in contrast to observations made here, has diameter $1.5 \times$ larger than that of E. coli [15].

Escherichia coli $\mathrm{BB} / 1$ was propagated in $2 \times \mathrm{LB}$ medium: 20 g tryptone, $10 \mathrm{~g}$ yeast extract, $5 \mathrm{~g} \mathrm{NaCl}$ in 1.01 of Milli-Q filtered water (Millipore/Sigma). A liquid culture was propagated to stationary phase at $30{ }^{\circ} \mathrm{C}$ just before use. The Lysinibacillus was thusly propagated in medium with $5 \mathrm{~g} \mathrm{KCl}, 10 \mathrm{~g}$ Bacto tryptone per $\mathrm{ml}$ of water with sterile $0.001 \mathrm{M} \mathrm{CaCl}_{2}$ subsequently added.

\section{In-gel propagation}

Gels for in-gel propagation were prepared by autoclaving and dissolving solid Seakem Gold (Lonza) agarose in a medium specified above. This solution was equilibrated at $50{ }^{\circ} \mathrm{C}$. Then, 3 drops (Lysinibacillus) or 5 drops (E. coli) of bacterial culture were mixed with $3.5 \mathrm{ml}$ of the molten agarose. This mixture was poured into a Petri plate over a $1.0 \%$ bottom layer agar gel in $10 \mathrm{~g}$ Bacto tryptone, $5 \mathrm{~g}$ $\mathrm{NaCl}$ in $1.0 \mathrm{l}$ of water, with sterile $0.001 \mathrm{M} \mathrm{CaCl}_{2}$ added for Lysinibacillus. After room temperature gelation, incubation was at $30{ }^{\circ} \mathrm{C}$ for the time indicated.

\section{Electron microscopy}

A 6-9 mm segment of agarose gel-supported bacterial lawn was excised at the time indicated. The lawn was added to $0.5 \mathrm{ml}$ of $4 \%$ formaldehyde, $1 \%$ glutaraldehyde, $0.11 \mathrm{M}$ sodium phosphate, $\mathrm{pH} 7.3$. After $2 \mathrm{~h}$ at room temperature, the gel was (1) washed for $5 \mathrm{~min}$ in $1.5 \mathrm{ml}$ of $0.1 \mathrm{M}$ sodium phosphate, $\mathrm{pH} 7.3$ and (2) post-fixed for $30 \mathrm{~min}$, at room temperature, in $1 \%$ osmium tetroxide in Zetterqvist's buffer [16].

The specimen was then dehydrated in $1.5 \mathrm{ml}$ of the following (in parentheses are number of changes/time [min] each): $70 \%$ ethanol (1/10), $95 \%$ ethanol (1/10), $100 \%$ ethanol $(2 / 10)$ and $100 \%$ propylene oxide (2/10). Next, Epon 812 , from Polysciences, was vacuum-infiltrated at room temperature in (1) a 50:50 mixture of resin with propylene oxide for $30 \mathrm{~min}$, followed by (2) undiluted resin for $30 \mathrm{~min}$. Finally, the resin was polymerized at $85{ }^{\circ} \mathrm{C}$ overnight, in a flat-embedding BEEM capsule.

An embedded gel was thin-sectioned with a Leica EM UC6 microtome and diamond knife. Sections were adhered to a 150-mesh copper grid, after color-selection [17] for $100 \mathrm{~nm}$ thickness. Sections were stained with $7 \%$ uranyl acetate for $30 \mathrm{~s}$, followed by Reynold's lead citrate [18] for $20 \mathrm{~s}$ both in a microwave oven $\left(0.035 \mathrm{~W} \mathrm{~cm}^{-3}\right)$.

EM was performed with a JEOL JEM-1400 electron microscope. Images were recorded with an AMT image capture engine Version: 7. Boxed regions in figures were contrast enhanced.

\section{Results}

\section{Distribution of cells}

EM revealed that most cells (82\% of 638 randomly selected) of a $16 \mathrm{~h}, 30{ }^{\circ} \mathrm{C}$-incubated E. coli lawn were clustered (Fig. 1a). Clusters had 8-80 bacteria (average, 30 , in 19 randomly selected clusters) with surrounding, inter-cluster, bacteria-free regions larger than clusters. The latter regions always had fibers indistinguishable from those previously seen [19] in agarose gels. These fibers (1) were best seen in higher-magnification micrographs (Fig. 1b; boxed region) and (2) indicated that gel breakage was not the source of the cell-free space.

The clusters were, in some locations, surrounded by individual cells (arrowheads in Fig. 1a, b). The latter could

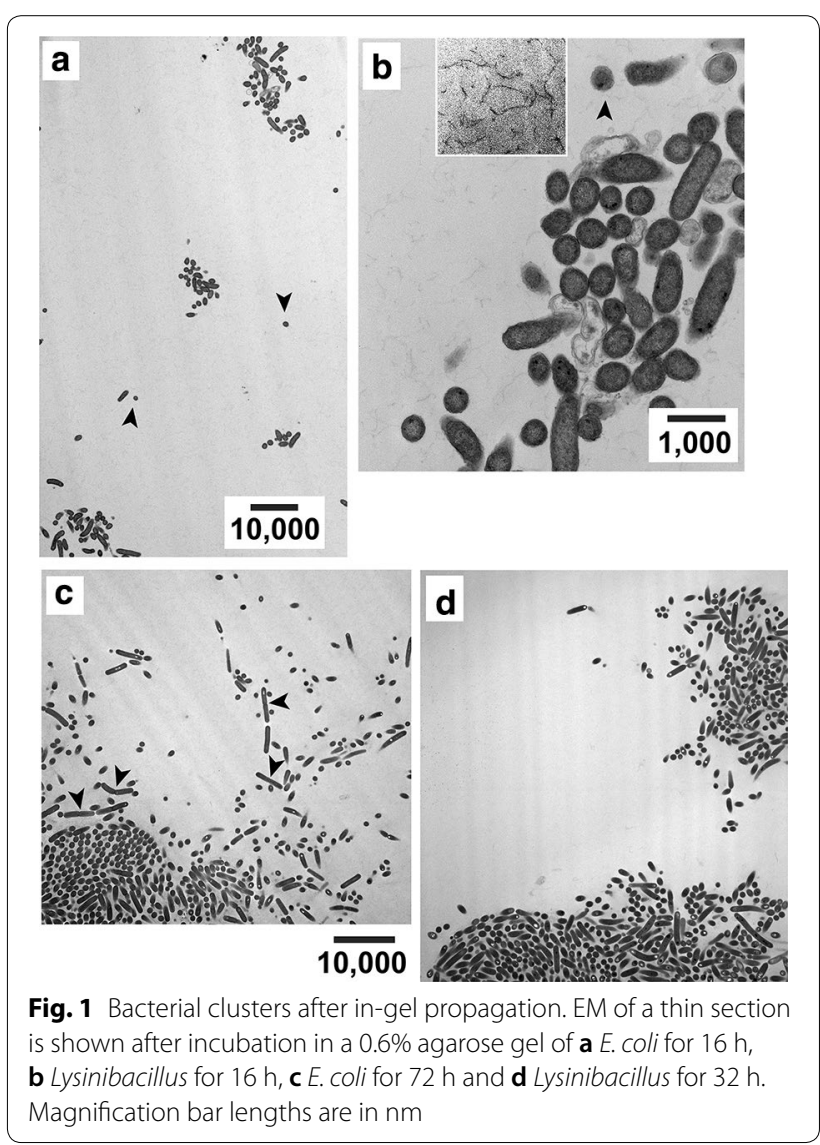


have resulted from (1) presence in a cluster that included cells not in the section, (2) post-replication migration away from a cluster and (3) non-replication.

Three characteristics of the clustering increased when the time of incubation was increased to $72 \mathrm{~h}$ : (1) percentage of cells cluster-associated (85-95\%, depending on field), (2) number of cells per cluster (100-400) and (3) average compactness of the clusters. In Fig. 1c, a densely packed cluster at bottom left appears to be merging with a less densely packed cluster at bottom right. The result was indistinguishable for Lysinibacillus except that the larger clusters appeared earlier (32 h: Fig. 1d).

By EM, Lysinibacillus and E. coli cells were $550-730 \mathrm{~nm}$ wide and $2000-5000 \mathrm{~nm}$ long. This width is smaller than the $1000 \mathrm{~nm}$ obtained by light microscopy for E. coli in liquid culture [8], perhaps because of cell shrinkage during dehydration ("Methods" section).

\section{Effects of clustered cells on gel fibers}

For 72 -h E. coli clusters in a $0.6 \%$ agarose gel, the density of inter-cell fibers varied from near-zero (arrowheads \#1 in Fig. 2a) to density (arrowheads \#2 in Fig. 2a) higher than the fiber density just outside of the cluster. Thus, within a cluster, growing cells appear to have dislocated fibers.

More dramatic evidence of gel fiber dislocation was finding of agarose fibers in bundles at the periphery (only) of E. coli clusters in a $0.6 \%$ gel. Arrowheads \#3 indicate these bundles in Fig. 2a. All observed fibers were assumed to be agarose because no fibers were seen emanating from most regions of cell surfaces. Thus, the assumption is that bundling was caused by gel compression caused by cluster growth caused, in turn, by growth

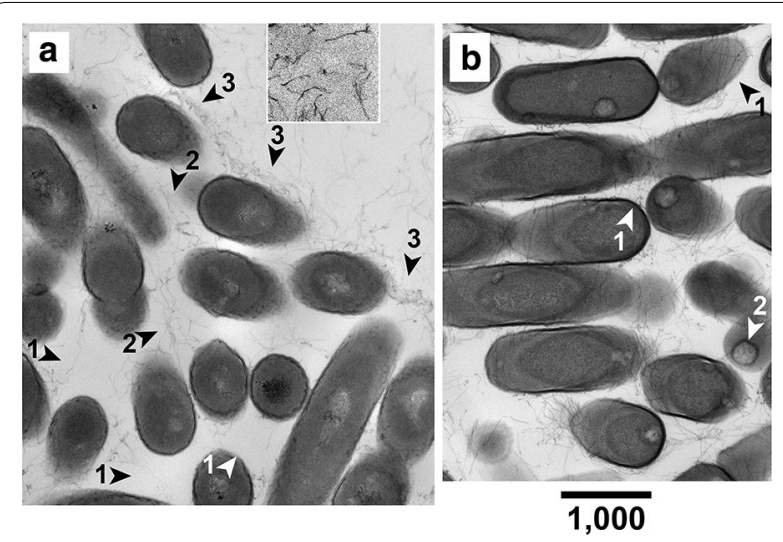

Fig. 2 Dislocation of gel fibers. Dislocation of agarose fibers is observed in thin sections of a cluster of $\mathbf{a} E$. coli grown for $72 \mathrm{~h}$ in a $0.6 \%$ agarose gel and $\mathbf{b}$ Lysinibacillus grown for $32 \mathrm{~h}$ in a $0.8 \%$ agarose gel (spores were seen in Lysinibacilli; arrowheads \#2). Magnification bar length is in $\mathrm{nm}$ of cells within the cluster. This compression implied reactive force on compression-generating cells (Newton's Second Law).

Results with Lysinibacillus lawns in a $0.8 \%$ gel also led to the conclusion of fiber dislocation by growing cells. Comparable variability of fiber density was seen (Fig. 2b). Sometimes, both cell and relatively concentrated gel fibers were superimposed. Cell growth apparently caused these fibers to wrap around the cell (arrowheads \#1 in Fig. 3b).

\section{Some aspects of cell position and orientation within a cluster}

Non-movement of cells after duplication in-gel should result in end-to-end chains of average length more than four cells. The reasons are that (1) progeny cells are arranged end-to-end immediately post-duplication [20] and (2) on average, more than two duplications occurred in the time of incubation. EM did sometimes reveal longitudinally sectioned chains two cells in length (Fig. 1c, arrowheads). But, longer chains were seen at a rate $\sim 1 \%$ of the number of chains two-long. Thus, movement of cells usually occurred after duplication.

Additional evidence of movement was that the 32-h Lysinibacillus and the 72-h E. coli clusters often had a sub-cluster array of 10-50 neighboring cells transversely sectioned, as seen in Fig. 1c for E. coli. These arrays had to be generated by bacterial motion because propagation

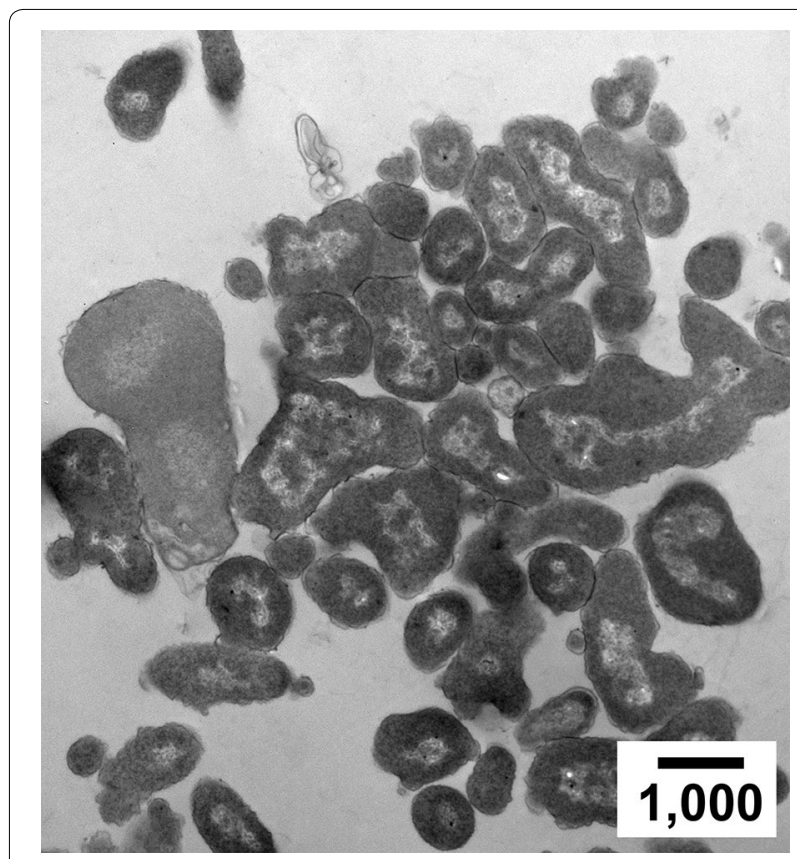

Fig. 3 Effects of adding $0.94 \mathrm{M}$ sucrose to the growth medium. Shape variability of cluster-associated $E$. coli cells is seen in a thin section of cells propagated for $48 \mathrm{~h}$ in a $0.6 \%$ agarose gel. Magnification bar length is in $\mathrm{nm}$ 
of inoculum-contained cellular aggregates did not cause them. Phase contrast microscopy revealed that aggregation was absent in the inoculum.

\section{Sucrose in the growth medium: deviations of cell shape}

We also performed EM of E. coli after in-gel propagation in medium with water activity $\left(\mathrm{a}_{\mathrm{w}}\right)$ lowered by inclusion of $0.94 \mathrm{M}$ sucrose $\left(\mathrm{a}_{\mathrm{w}}=0.97\right.$ [21]). Some phage T3 mutants have displayed an informative phenotype in this medium [13]. Biofilms were sometimes favored by lowered $a_{w}$ (cystic fibrosis-generating biofilms, for example [3]).

In this lowered- $\mathrm{a}_{\mathrm{w}}$ medium, cell clustering was accompanied by cell shape polymorphism never observed in unsupplemented medium. After 48-h incubation, most cells lost their rod shape (Fig. 3). Others may have been shape-altered, but not sectioned in a plane that revealed altered shape. The shape appeared not to be pre-determined, but to be controlled, in part, by volume exclusion of neighboring cells.

\section{Discussion}

\section{In-gel distribution of cells of a lawn}

The observed cell clustering must have explanation based on the surrounding gel fibers. The reason is that clusterinhibiting competition for nutrients and oxygen increases as clusters become larger and more compact.

At least two possible gel-derived, cluster-encouraging effects are suggested by our observation that gel fiber dislocation accompanies bacterial growth (Fig. 2a, b). The first occurs via (1) variable local gel strength and (2) bacterial growth rate that increases as local gel strength decreases. The asymmetric shape of some clusters (Fig. 1a, b) is explained by (1) and (2), together with asymmetric zones of local gel weakness.

The second possible cluster-encouraging effect is bacterial growth-dependent force that (1) is exerted by clusters against gel fibers and (2) increases as cluster size and density increase. This force would promote additional cluster-associated bacterial growth.

A clustering-amplified force might occur via combining of forces generated by bacteria throughout the cluster and/or inhibition of growth at a cluster surface. In either case, clustered cells are force-biased to outgrow cells that are either un-clustered or in smaller clusters.

For completeness, we note the (untested) possibility that clustering is further promoted by cellular secretions. This possibility includes improved production and use of growth factors via specialization and cross-feeding.

The observed side-by-side clustering is impossible via cell duplication without further translational and rotational cell movement. The presumed driver is reactive force exerted by dislocated gel fibers on bacterial cells.

\section{In-gel changes in cell shape at lowered water activity}

The observation of sucrose-induced, neighboring cellcontrolled shape distortion in Fig. 3 is, to our knowledge, the first such observation. We do not have evidence of mechanistic details. We hypothesize that neighboring cells control shape because the sucrose over-rides mechanisms for specifying rod-like shape, possibly by increasing intracellular pressure.

\section{Consequences for understanding both in-gel phage propagation and biofilms}

The clustering observed here renders certain that phages T3, T7 and G propagate in conditions that vary, when in laboratory-generated, agarose (and presumably agar) gelsupported bacterial lawns. Nutrient concentrations will vary with position in and near clusters. In addition, cells will experience a variable gel fiber-derived pressure.

Previous studies have considered the following biofilmgenerating factors: (1) characteristics of bacterial attachment surfaces [22], (2) availability and type of nutrients [23], (3) availability of oxygen [24], (4) water flow [25], (5) electrical activity of cells [26] and (6) quorum-sensing of cells [22]. The data presented here implicate clustering not, to our knowledge, a factor previously considered. Clustering would cause biofilm-associated bacterial strains to be mixed primarily as clusters, not single cells.

\section{Limitations}

1. We have not repeated the analysis performed here with biofilms.

2. Although the fibers in our images do not appear to emanate from bacterial cells and look like agarose fibers, a chance exists that some of them are secreted by the cells.

3. The levels of cluster-associated nutrients and oxygen have not been measured.

\section{Abbreviations \\ $a_{w}$ : water activity; EM: electron microscopy; $2 \times P_{E}$ : diameter of the effective pore of an agarose gel.}

Authors' contributions

PS designed the study, wrote the manuscript and performed EM. BH embedded the specimens, performed the thin sectioning and maintained the electron microscope. ETW performed the phage propagation, excision of plaques and fixation. All authors read and approved the final manuscript.

\footnotetext{
Author details

${ }^{1}$ Department of Biochemistry and Structural Biology, The University of Texas Health Science Center, 7703 Floyd Curl Drive, San Antonio, TX 78229-3900,
} 
USA. ${ }^{2}$ Department of Pathology, The University of Texas Health Science Center, 7703 Floyd Curl Drive, San Antonio, TX 78229-3900, USA.

\section{Acknowledgements}

We thank the Department of Pathology at the University of Texas Health Science Center, San Antonio, for provision of the facilities used for electron microscopy.

\section{Competing interests}

The authors declare that they have no competing interests.

\section{Availability of data and materials}

All data generated or analyzed during this study are included in this published article.

\section{Consent to publish}

Not applicable.

\section{Ethics approval and consent to participate}

Not applicable.

\section{Funding}

We thank the San Antonio Area Foundation for financial support. The funding body had no role in design of the study and collection, analysis, and interpretation of data and in writing the manuscript.

\section{Publisher's Note}

Springer Nature remains neutral with regard to jurisdictional claims in published maps and institutional affiliations.

Received: 3 July 2018 Accepted: 30 September 2018 Published online: 04 October 2018

\section{References}

1. Kropinski AM, Mazzocco A, Waddell TE, Lingohr E, Johnson RP. Enumeration of bacteriophages by double agar overlay plaque assay. Methods Mol Biol. 2009;501:69-76.

2. Francis F, Miller R, Nagra M. Phage overlay assay for quantification of infectious bacteriophage particles. JEMI Meth. 2017;1:18-21.

3. Hall-Stoodley L, Costerton JW, Stoodley P. Bacterial biofilms: from the natural environment to infectious diseases. Nat Rev Microbiol. 2004:2:95-108

4. Lopez D, Vlamakis H, Kolter R. Biofilms. Cold Spring Harb Perspect Biol. 2010;2:a000398.

5. Pattem J, Davrandi M, Aguayo S, Allan E, Spratt D, Bozec L. A multi-scale biophysical approach to develop structure-property relationships in oral biofilms. Sci Rep. 2018;8:5691.

6. Tuson HH, Renner LD, Weibel DB. Polyacrylamide hydrogels as substrates for studying bacteria. Chem Commun. 2012;48:1595-7.

7. Mackie W, Sellen DB, Sutcliffe J. Spectral broadening of light scattered from polysaccharide gels. Polymer. 1978;19:9-15.
8. Gangan MS, Athale CA. Threshold effect of growth rate on population variability of Escherichia coli cell lengths. R Soc Open Sci. 2017:4:160417.

9. Griess GA, Moreno ET, Easom RA, Serwer P. The sieving of spheres during agarose gel electrophoresis: quantitation and modeling. Biopolymers. 1989;28:1475-84

10. Kandemir N, Vollmer W, Jakubovics NS, Chen J. Mechanical interactions between bacteria and hydrogels. Sci Rep. 2018:8:10893.

11. Tuson HH, Auer GK, Renner LD, Hasebe M, Tropini C, Salick M, Crone WC, Gopinathan A, Huang KC, Weibel DB. Measuring the stiffness of bacterial cells from growth rates in hydrogels of tunable elasticity. Mol Microbiol. 2012;84:874-91.

12. Griess GA, Guiseley KB, Miller MM, Harris RA, Serwer P. The formation of small-pore gels by an electrically charged agarose derivative. J Struct Biol. 1998;123:134-42.

13. Serwer P, Wright ET. Testing a proposed paradigm shift in analysis of phage DNA packaging. Bacteriophage. 2016;6:e1268664.

14. Donelli G. Isolamento di un batteriofago di eccezionali dimensioni attivo su B. megatherium. Atti Accad Naz Lincei-Rend Clas Sci Fis Mat Nat. 1968:44:95-7.

15. Bunk B, Schulz A, Stammen S, Münch R, Warren MJ, Rohde M, Jahn D, Biedendieck R. A short story about a big magic bug. Bioeng Bugs. 2010;1:85-91.

16. Glauert A. Fixation, dehydration and embedding of biological specimens. New York: North-Holland Publishing Co; 1975.

17. Peachey LD. Thin sections. I. A study of section thickness and physical distortion produced during microtomy. J Biophys Biochem Cytol. 1958;4:233-42.

18. Reynolds ES. The use of lead citrate at high $\mathrm{pH}$ as an electron-opaque stain in electron microscopy. J Cell Biol. 1963;17:208-12.

19. Griess GA, Guiseley KB, Serwer P. The relationship of agarose gel structure to the sieving of spheres during agarose gel electrophoresis. Biophys $\mathrm{J}$. 1993;65:138-48.

20. Jacobs C, Shapiro L. Bacterial cell division: a moveable feast. Proc Natl Acad Sci USA. 1999;96:5891-3.

21. Food-safety. Water activity of sucrose and $\mathrm{NaCl}$ solutions. In: $\mathrm{BC}$ Centre for Disease Control. 2010. http://ucfoodsafety.ucdavis.edu/files/133655.pdf. Accessed May 82018.

22. Gu H, Hou S, Yongyat C, De Tore S, Ren D. Patterned biofilm formation reveals a mechanism for structural heterogeneity in bacterial biofilms. Langmuir. 2013;29:11145-53.

23. Speranza B, Corbo MR, Sinigaglia M. Effects of nutritional and environmental conditions on Salmonella sp. biofilm formation. J Food Sci. 2011;76:M12-6.

24. Ahn S-J, Burne RA. Effects of oxygen on biofilm formation and the AtlA autolysin of Streptococcus mutans. J Bacteriol. 2007;189:6293-302.

25. Hödl I, Mari L, Bertuzzo E, Suweis S, Besemer K, Rinaldo A, Battin TJ. Biophysical controls on cluster dynamics and architectural differentiation of microbial biofilms in contrasting flow environments. Environ Microbiol. 2014;16:802-12.

26. Masi E, Ciszak M, Santopolo L, Frascella A, Giovannetti L, Marchi E, Viti C, Mancuso S. Electrical spiking in bacterial biofilms. J R Soc Interface. 2015;12:20141036.

Ready to submit your research? Choose BMC and benefit from:

- fast, convenient online submission

- thorough peer review by experienced researchers in your field

- rapid publication on acceptance

- support for research data, including large and complex data types

- gold Open Access which fosters wider collaboration and increased citations

- maximum visibility for your research: over 100M website views per year

At BMC, research is always in progress.

Learn more biomedcentral.com/submissions 